Metallophysics and Advanced Technologies

Металофіз. новітні технол.

Metallofiz. Noveishie Tekhnol.

2021, vol. 43, No. 9, pp. 1167-1173

https://doi.org/10.15407/mfint.43.09.1167

Reprints available directly from the publisher
(C) 2021 G. V. Kurdyumov Institute for Metal Physics, National Academy of Sciences of Ukraine Published by license under

the G. V. Kurdyumov Institute for Metal PhysicsN.A.S. of Ukraine Publishers imprint. Printed in Ukraine.

PACS numbers: 07.55.Db, 61.72.-y, 61.82.Bg, 62.20.-x, 81.20.Vj, 81.40.Wx

\title{
Peculiarities of Structure Formation of Welded Joint during Underwater Welding at External Electromagnetic Effect
}

\author{
S. Yu. Maksymov, O. O. Prilipko, O. M. Berdnikova, I. I. Alekseienko, \\ and Ye. V. Polovetskiy
}

E. O. Paton Electric Welding Institute, N.A.S. of Ukraine,

11 Kazymyr Malevych Str.,

UA-03150 Kyiv, Ukraine

Water medium harms the quality of welded joints and their mechanical properties. One of the effective ways for solving this problem is the application of the effect of external electromagnetic field on a liquid metal pool. The aim of carried investigations is the determination of the efficiency of use of external electromagnetic effect for the regulation of structural transformations in wet underwater welding with flux-cored wire. As determined, the width of crystalline particles can be reduced nearly two times and grains of the weld metal and heat affected zone close to a fusion line can be 1.3-1.4 time refined. As shown, the application of external electromagnetic effect prevents the appearance of gradients of grain size along the fusion line from face to weld root.

Key words: underwater welding, flux-cored wire, external electromagnetic field, heat affected zone, structure of weld metal.

Водне середовище чинить негативний вплив на якість зварних з'єднань і їхні механічні властивості. Одним з ефективних шляхів вирішення цієї проблеми є використання дії зовнішнього електромагнетного поля на рідкометалеву ванну. Метою проведених досліджень було визначення ефективності використання зовнішньої електромагнетної дії для керування структурними перетвореннями у разі мокрого підводного зварювання порошковим дротом. Встановлено можливість зменшення ширини кристалітів у центрі металу шва практично вдвічі і подрібнення зерен металу шва

Corresponding author: Serhiy Yuriyovych Maksymov

E-mail:maksimov@paton.kiev.ua

Citation: S. Yu. Maksymov, O. O. Prilipko, O. M. Berdnikova, I. I. Alekseienko, and Ye. V. Polovetskiy, Peculiarities of Structure Formation of Welded Joint during Underwater Welding at External Electromagnetic Effect, Metallofiz. Noveishie Tekhnol., 43, No. 9: 1167-1173 (2021), DOI: 10.15407/mfint.43.09.1167. 
та зони термічного впливу поблизу лінії стоплення в $1,3-1,4$ рази. Показано, що застосування зовнішньої електромагнетної дії запобігає виникненню градієнтів розмірів зерен вздовж лінії стоплення від лицевої поверхні до кореня шва.

Ключові слова: підводне зварювання, порошковий дріт, зовнішнє електромагнетне поле, зона термічного впливу, структура металу зварного шва.

(Received July 7, 2019; in final version, April 13, 2021)

\section{INTRODUCTION}

Difficulties in obtaining the required level of properties of welded joints made in an aqueous medium necessitate the use of additional measures [1-4]. For example, to control the structure of the weld metal, it is proposed to alloy $[5,6]$. To increase resistance to the formation of cold cracks, it is recommended to use temper bead [7]. Earlier experiments at the E. O. Paton Electric Welding Institute, NAS of Ukraine on underwater welding of low-alloy low-carbon steels showed that application of external electromagnetic effect (EEE) in the process of welding affects mechanical properties of welded joints [8-10]. These characteristics are structure sensitive; therefore, detection of regularities of formation of the welded joint structure under EEE provides the possibility to predict structure behaviour in the process of operation.

The aim of carried investigations is the determination of EEE influence on structural transformations in welded joints made under water.

\section{EXPERIMENTAL}

Surfacing on plates of steel St3 of $12 \mathrm{~mm}$ thickness is carried out in a

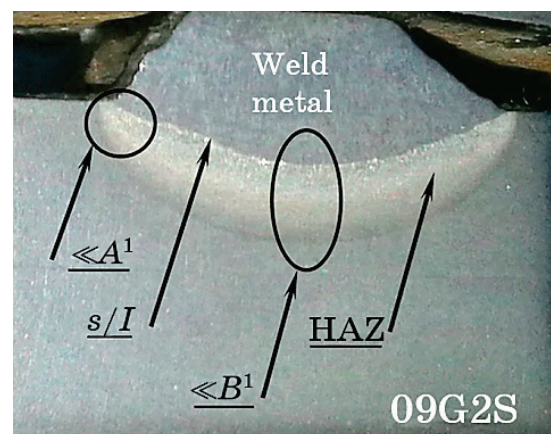

$a$

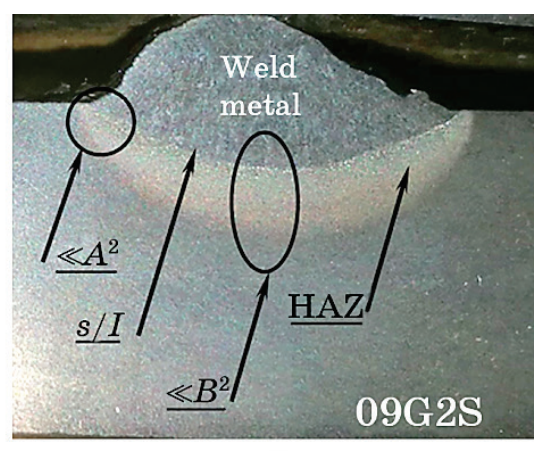

$b$

Fig. 1. General appearance of samples: without $\operatorname{EEE~(a),~with~} \operatorname{EEE~}(b)$. 'A' - in the place of base to deposited metal fusion, 'B' - zone in weld root. 
laboratory pool at $1 \mathrm{~m}$ depth using flux-cored wire at $U_{\mathrm{a}}=32 \mathrm{~V}$, $I_{\mathrm{w}}=180 \mathrm{~A}, V_{\mathrm{w}}=8 \mathrm{~m} / \mathrm{h}$ mode. The examinations are carried out by methods of optical metallography using Neophot-32 and Versamet-2 (Japan) microscopes and analytical scanning electron microscopySEM (SEM-515 microscope of Philips Company, Netherlands).

The samples are examined in the areas of weld metal, fusion line and heat affected zone in the place of transfer to base metal and in the lower (root) part of deposit-overheating zone (coarse grain) HAZ I, grain-refined zone HAZ II, area of incomplete grain-refined zone HAZ III, recrystallized zone HAZ IV, Fig. 1.

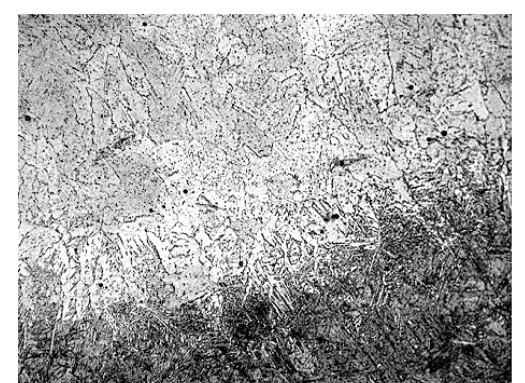

$a$

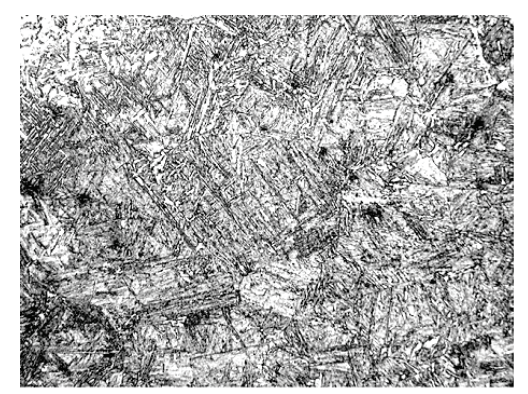

$c$

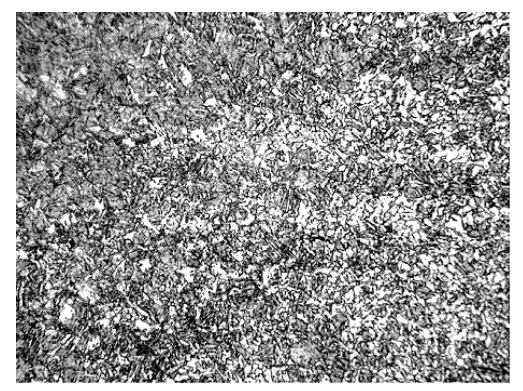

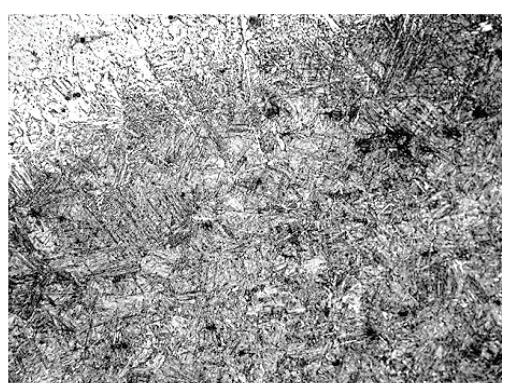

$b$

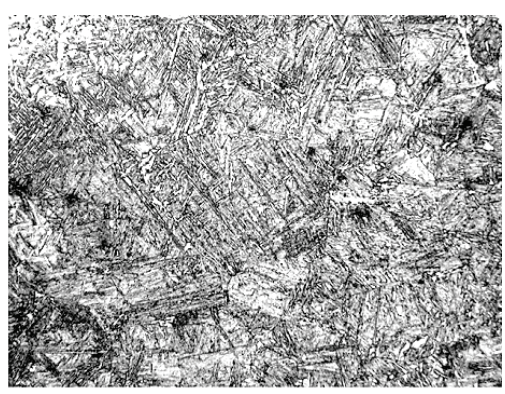

$d$

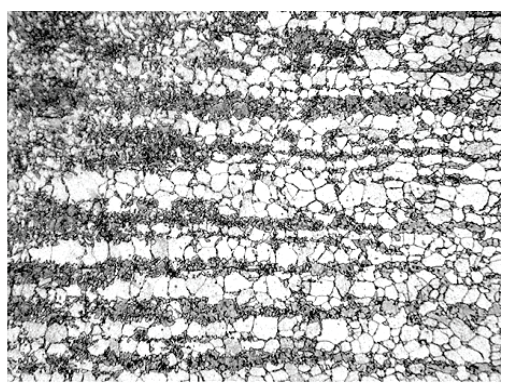

$f$

Fig. 2. Microstructure of metal of sample welded without EEE, in zone 'A1': fusion line $(\times 250)(a, b)$, I HAZ (coarse grain) $(c)$, HAZ II (grain-refined) $(d)$, HAZ III (incomplete grain-refined) $(e)$, HAZ IV (recrystallized) $(f), \times 500$. 


\section{RESULTS AND DISCUSSION}

Examination of the sample without EEE in zones 'A1' and 'B1' showed that at transfer from base to deposited metal fusion zone- 'A', Fig. 2, before the area in weld root- ' $\mathrm{B}$ ', Fig. 3 , there is noticeable coarsening (3 times) of grain structure (on average from $D_{\mathrm{g}}=25 \mu \mathrm{m}$ to $D_{\mathrm{g}}=60 \mu \mathrm{m}$ ). Presence of grain size gradient can result in strength properties gradient and decrease of metal toughness.

Bainite (B) structure is formed in HAZ metal close to face surface (zone A2) in welding using EEE, Fig. 4. In overheating zone (HAZ Icoarse grain), the grain size makes $D_{g}=10-30 \mu \mathrm{m}$ at $H V=3360-3830$ $\mathrm{MPa}$. In grain-refined zone (HAZ II) and incomplete grain-refined zone (HAZ III) the size of bainite grains makes $D_{\mathrm{g}}=10-15 \mu \mathrm{m}$ and $D_{\mathrm{g}}=8-12$ $\mu \mathrm{m}$ at $H V=3660-3510 \mathrm{MPa}$ and $H V=3220-3510 \mathrm{MPa}$, respectively. In the recrystallized zone (HAZ IV) there is the formation of ferritebainite (F-B) structure with $D_{\mathrm{g}}=5-8 \mu \mathrm{m}$.

In the root part of this sample (zone 'B2'), Fig. 5, size of the crystalline particles in the weld metal close to the fusion line makes $h_{\mathrm{cr}}=100-$ $300 \mu \mathrm{m}$ at $H V=1700-1870 \mathrm{MPa}$. From HAZ side in the overheating zone (HAZ I-coarse grain) the grain size makes $D_{\mathrm{g}}=20-50 \mu \mathrm{m}$ at

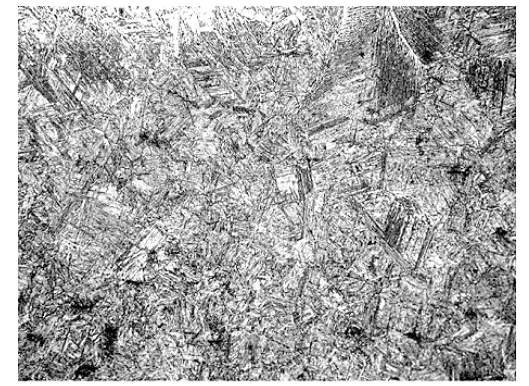

$a$

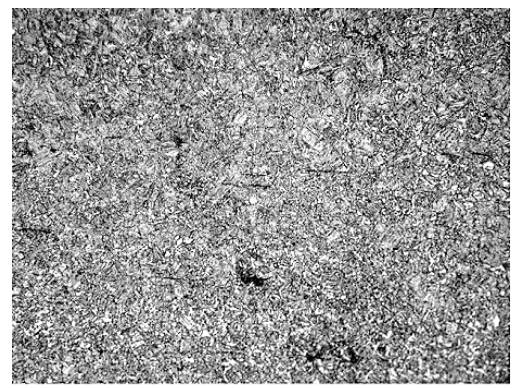

c

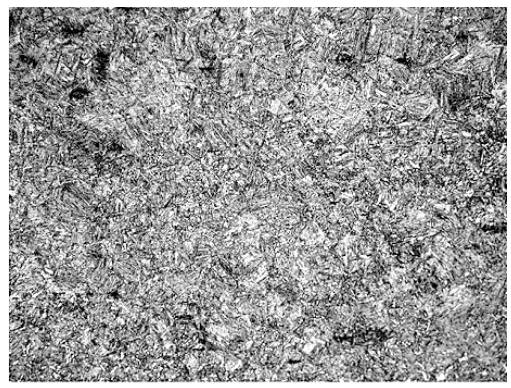

$b$

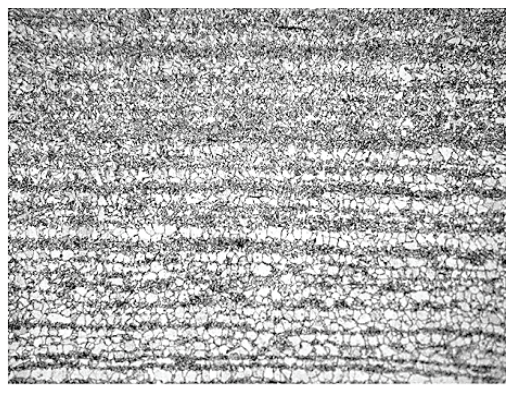

d

Fig. 3. Microstructure of metal of sample, welded without EEE, in zone 'B1': HAZ (coarse grain) ( $a$ ), HAZ II (grain-refined) (b), HAZ III (incomplete grainrefined) (c), HAZ IV (recrystallized) $(d), \times 250$. 
$H V=2970-3220 \mathrm{MPa}$. In the grain-refined zone (HAZ II) and incomplete grain-refined zone (HAZ III) the size of bainite grains makes $D_{\mathrm{g}}=10-20 \mu \mathrm{m}$ and $D_{\mathrm{g}}=8-12 \mu \mathrm{m}$ at $H V=3090-3220 \mathrm{MPa}$ and $H V=2540 \mathrm{MPa}$, respectively. In the recrystallized zone (HAZ IV) there is formation of ferrite-bainite $(\mathrm{F}-\mathrm{B})$ structure with $D_{\mathrm{g}}=4-8 \mu \mathrm{m}$ and $H V=2130-2360 \mathrm{MPa}$.

Comparison of the structural changes in HAZ metal of the examined samples showed the next. In the sample made using EEE, the width of

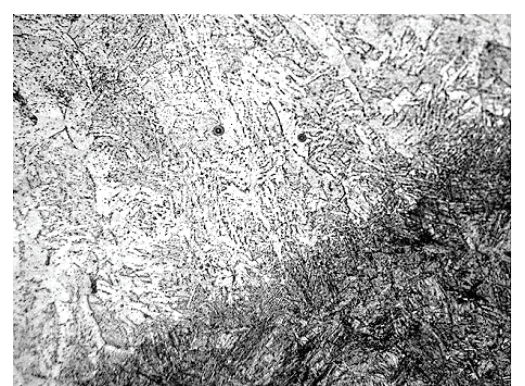

$a$

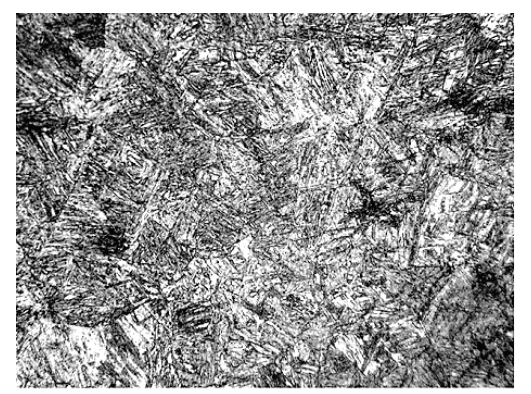

$c$

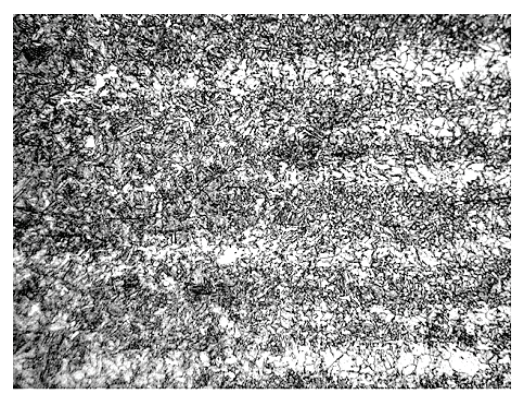

e

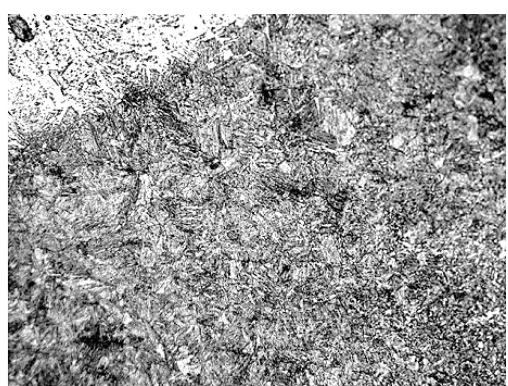

b

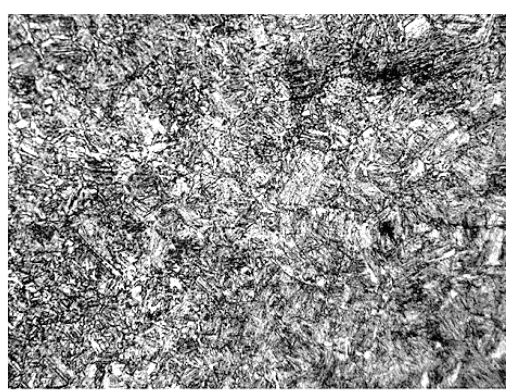

$d$

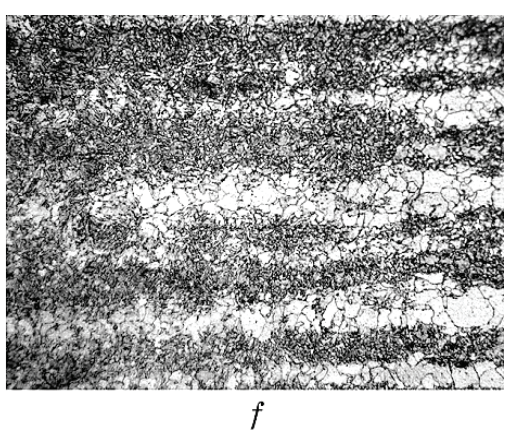

Fig. 4. Microstructure of metal of sample welded with EEE, (in zone 'A2'): fusion line $(\times 250)(a, b)$, HAZ I (zone of coarse grain) $(c)$, HAZ II (grainrefined zone) (d), HAZ III (incomplete grain-refined zone) (e), HAZ IV (recrystallized zone) $(f), \times 500$. 


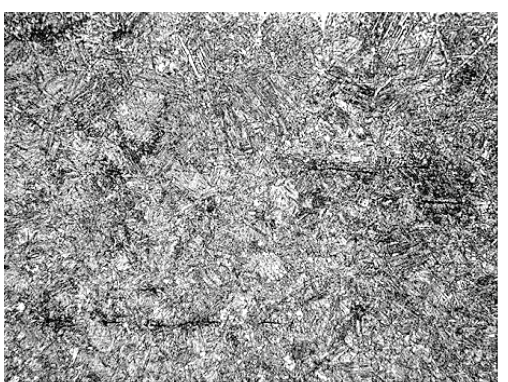

$a$

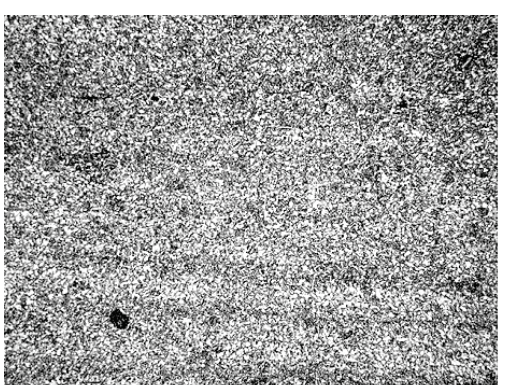

$c$

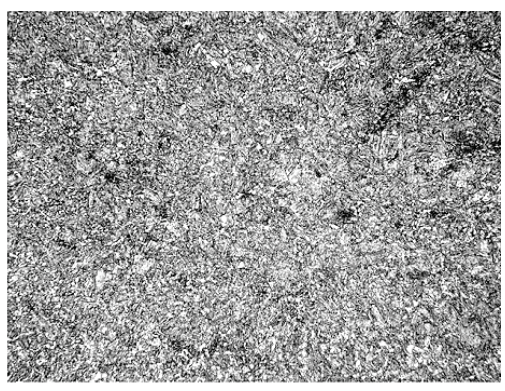

$b$

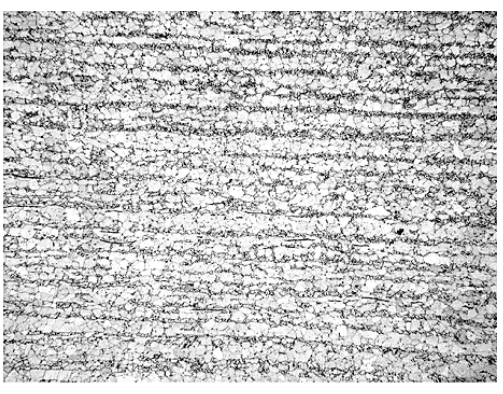

$d$

Fig. 5. Microstructure of metal of sample made with EEE (in zone 'B2'): HAZ I (zone of coarse grain) (a), HAZ II (grain-refined zone) (b), HAZ III (incomplete grain-refined zone) $(c)$, HAZ IV (recrystallized zone) $(d), \times 250$.

crystalline particles reduces virtually two times in the weld centre. Close to the fusion line (deposited metal) as well as in overheating zone (HAZ I-coarse grain zone), there is 1.3-1.4 time grain refinement. Thus, the width of crystalline particles $h_{\text {cr }}$ (from the deposited metal side) and size of grains (HAZ I) is reduced in the weld metal and HAZ of samples with EEE in zones 'A2' and 'B2' at the absence of noticeable gradients along the fusion line.

\section{CONCLUSION}

There is significant coarsening of grains of welded joint metal structure in underwater welding by in-house technology (without EEE application) at transfer from base metal fusion zone and deposited metal ('A') on the face surface up to the examination zone in weld root ('B').

Application of EEE leads to virtually two times decrease of the width of crystalline particles in the weld centre. Close to the fusion line (deposited metal) as well as in overheating zone (HAZ I-zone of coarse grain), there is 1.3-1.4 time grain structure refinement.

In the sample, made using EEE, there is no noticeable gradient of sizes of structural constituents at transfer along the fusion line from 
face to weld root. It should provide uniform distribution of level of strength and ductility on the depth of base metal penetration.

\section{REFERENCES}

1. J. Łabanowski, D. Fydrych, and G. Rogalski, Advances in Materials Science, 8, Iss. 3: 11 (2008).

2. Kunthlesh Kumar and Rickramjeet Singh, J. Mechanical and Civil Engineering, 1, Iss. 12: 28 (2015).

3. Harish Kumar Patel, Vipin Kumar Patel, Md. Gufran, and Rajkumar Bareth, Int. J. Research, 3, Iss. 01: 493 (2016).

4. Mayank Chandra Joshi, Deepak Singh Rautela, Rajat Chauhan, and Sumit Suyal. J. Mechanical and Civil Engineering, 13, Iss. 5: 74 (2016).

5. Duo Liu, Ning Guo, Changsheng Xu, Hongliang Li, Ke Yang, and Jicai Feng, J. Materials Engineering and Performance, 26, Iss. 5: 23508 (2017).

6. Ning Guo, Duo Liu, Wei Guo, Haixin Li, and Jicai Feng, Materials Design, 77: 25 (2015).

7. D. Fydrych, A. Swierczynska, G. Rogalski, and J. Labanowski, Advances in Materials Science, 16, No. 4: 5 (2016).

8. R. N. Ryzhov, S. Yu. Maksimov, and E. A. Prilipko, Bulletin of NTUU 'KPI', No. 48: 226 (2006) (in Russian).

9. S. Yu. Maksimov, V. I. Kozhukhar, R. N. Ryzhov, and E. A. Prilipko, Paton Welding J., No. 11: 49 (2004).

10. N. V. Zaytseva, S. M. Zakharov, S. Yu. Maksimov, and E. A. Prilipko, Metallofiz. Noveishie Tekhnol., 31, No. 11: 1589 (2009) (in Russian). 